\title{
KATA SERAPAN DALAM BAHASA JEPANG
}

\author{
Elizabeth Ika Hesti Aprilia Nindia Rini \\ Fakultas Ilmu Budaya Universitas Diponegoro \\ Email: eliz_ikahesti@yahoo.co.id
}

\begin{abstract}
(Title: Gairaigo In Japanese) Loan word was born as a result of cultural and language contact with other countries. Loan word in Japanese or commonly known as gairaigo is known generally comes from English, but not entirely so. The purpose of this research is to describe the origin, form, and formation process of the loan word in Japanese, The method used is descriptive method. As the result of the research, it is found that Japanese loan word is not only from English; the form of loan word consists of 3 - 7 syllables; and entered into Japanese through adaptation and adoption process.
\end{abstract}

Keywords: gairaigo; adaptation; adoption

\section{PENDAHULUAN}

Setiap bahasa memiliki kata serapan sebagai pengaruh interaksinya dengan bangsa lain. Kata serapan dalam bahasa Indonesia misalnya, selain berasal dari bahasa daerah juga berasal dari bahasa asing seperti Portugis, Inggris, Belanda, Cina, Arab, dan lainnya. Menurut Imran (2005:17), melalui kata serapan yang berasal dari berbagai bahasa diperoleh banyak sinonim yang dapat digunakan untuk berekspresi dengan presisi lebih tinggi.

Demikian pula halnya bahasa Jepang, kata serapan dalam bahasa Jepang memperkaya kosakata bahasa Jepang dan membuat bahasa asing lebih dapat diterima (Kawamoto dalam Soelistyowati, 2010:153).

Kata serapan bahasa Jepang umumnya diketahui berasal dari bahasa Inggris seperti ドア doa 'pintu' yang berasal dari kata door, スカート sukaato 'rok' yang berasal dari kata skirt, アイス クリーム aisukuriimu 'es krim' yang berasal dari kata ice cream, dan lain-lain. Namun demikian tidak semua kata serapan bahasa Jepang berasal dari bahasa Inggris. Untuk itu penelitian ini bertujuan untuk memaparkan kata serapan bahasa Jepang dilihat dari asal usul, bentuk, dan proses pembentukannya.

Penelitian terdahulu mengenai kata serapan pernah dilakukan oleh Imran (2005) mengenai kata serapan dalam bahasa Indonesia. Sebagai hasil penelitian ditemukan bahwa kata serapan bahasa Indonesia adalah kata asing atau daerah yang masuk ke dalam kosa kata bahasa Indonesia (Bloomfield, 1996:445). Menurut Imran kata serapan bahasa Indonesia terdiri dari kata serapan budaya dan mesra. Kata serapan budaya (berasal dari bahasa Sansekerta, Arab, Portugis, dan Inggris) masuk ke dalam bahasa Indonesia melalui pendidikan, ilmu dan teknologi, agama, dan perdagangan. Kata serapan mesra (berasal dari bahasa Belanda dan Cina) masuk ke dalam bahasa Indonesia melalui perang, penjajahan, dan imigrasi.

Proses penyerapan kata asing ke dalam bahasa Indonesia terjadi melalui proses adaptasi dan adopsi. Adaptasi dilakukan dengan penyesuaian unsur-unsur bahasa asing dengan kaidah bahasa Indonesia, diantaranya misalnya sufiks -isme bahasa Belanda yang terdapat pada 
kata nasionalisme, patriotisme, feminisme; kata serapan yang pada bahasa aslinya terdiri dari satu suku kata menjadi dua suku kata, misalnya pada kata lamp menjadi lampu, boek menjadi buku, zak menjadi saku, koek menjadi kukis; adaptasi kata inti dalam bahasa Indonesia yang biasanya berpotensi menjadi inisial misalnya pada kata hand body lotion dalam bahasa Inggris diserap dalam bahasa Indonesia menjadi henbodi, training's pak dalam bahasa Belanda diserap dalam bahasa Indonesia menjadi trening; dan lain-lain. Sementara itu adopsi adalah kata serapan yang masuk ke dalam kosa kata bahasa Indonesia melalui perubahan pada konsep dan arti. Adopsi terdiri dari a) adopsi konsep dan arti secara utuh, misalnya kata presiden, nasional, dan fonem; b) adopsi konsep, misalnya kata Allah konsepnya monotheis dalam bahasa Indonesia menjadi kata Tuhan; c) adopsi konsep tetapi dideskripsikan juga ke dalam bahasa Indonesia, misalnya kata spoor dalam bahasa Indonesia dideskripsikan sebagai kereta api; d) terjemahan langsung, misalnya frasa bahasa Inggris fifteen seconds from now menjadi 'lima belas detik dari sekarang'; e) adopsi kata dengan perubahan arti, misalnya kata retool dalam bahasa Inggris berarti 'mengganti peralatan' menjadi ritul yang berarti dipecat.

Berbeda dengan penelitian Imran yang mengkaji kata serapan bahasa Indonesia, penelitian ini akan mengkaji kata serapan dalam bahasa Jepang. Permasalahan yang diangkat pada penelitian ini adalah asal-usul, bentuk, dan proses pembentukan kata serapan dalam bahasa Jepang. Tujuan penelitian ini adalah untuk memaparkan asal, bentuk, dan pembentukan kata serapan dalam bahasa Jepang.

\section{METODE}

Penelitian ini merupakan penelitian studi pustaka, yaitu studi yang teknik pengumpulan datanya dilakukan dengan melakukan penelaahan terhadap berbagai buku, literatur, catatan, serta berbagai laporan yang berkaitan dengan masalah yang ingin dipecahkan (Nazir:1988). Kemudian hasil penelaahan tersebut akan dipaparkan dengan metode deskriptif yang bertujuan membuat gambaran, lukisan secara sistematis, faktual dan akurat mengenai data, sifat-sifat serta hubungan fenomena-fenomena yang diteliti (Djajasudarma, 2010 : 9).

\section{HASIL DAN PEMBAHASAN}

Menurut Akimoto (2002:62), berdasarkan asal katanya, kata bahasa Jepang diklasifikasikan menjadi kata asli (固有語 koyuugo) dan kata pinjaman (借用 語 shakuyougo). Kata asli terdiri dari wago 和語 yang merupakan kata asli Jepang; kata yang masuk Jepang dari Cina sejak zaman purba; dan kata yang berasal dari bahasa Ainu. Sedangkan kata pinjaman terdiri dari kango 漢語 yang merupakan kata asli Cina; kata asli Jepang yang dibaca secara onyomi; dan gairaigo 外来語 yang merupakan kata serapan bahasa asing. Kemudian untuk melengkapi klasifikasi tersebut ditambahkan pula konshugo 昆種語 yang merupakan kata yang dihasilkan dari penggabungan beberapa jenis kata tersebut.

Berikut ini akan dibahas mengenai asal, bentuk, dan proses pembentukan kata serapan bahasa Jepang atau gairaigo 外 来語.

\section{Asal Kata Serapan Bahasa Jepang (Gairaigo 外来語)}

Gairaigo 外来語 atau disebut pula yougo 洋語 adalah kata pinjaman yang terutama berasal dari turunan bahasa Eropa yang bentuk dan maknanya diubah sesuai kaidah bahasa Jepang. Yang termasuk gairaigo diantaranya kata-kata yang tercipta di Jepang yaitu wasei eigo 和製英 語 seperti naitaa ナイター, teeburu supiichi テーブルスピーチ; dan kata yang maknanya berbeda dari bahasa aslinya 
Tersedia online di http://ejournal.undip.ac.id/index.php/kiryoku

seperti posuto ポスト, arakaruto ア ラ カルト.

Menurut Akimoto lebih dari $80 \%$ kata serapan bahasa Jepang merupakan kata pinjaman dari bahasa Inggris. Namun demikian apabila ditelusuri sejarahnya, kata serapan bahasa Jepang pertama dibawa oleh misionaris dari Portugis pada abad 16, misalnya kata yang menyatakan nama tempat seperti Ajiaアジア, Oranda オラ ンダ; nama makanan misalnya pan パン, tenpura テンプラ. Melalui bahasa Spanyol dan Portugis masuk kata-kata seperti kabocha カボチャ (dari Kamboja), saraca サラサ (dari bahasa Jawa), tabako タバコ (dari bahasa Haiti di kepulauan India Barat), dan lain-lain.

Pada abad 17, karena pengaruh politik isolasi Jepang, masuk kata yang berasal dari bahasa Belanda yaitu arukooru アルコール, garasu ガラス, gomu ゴム, biiru ビール, dan lain-lain.

Pada awal abad 19, di akhir zaman feodal mulai masuklah kata-kata yang berasal dari bahasa Inggris dan bahasa Perancis (misalnya mayoneezu マヨネーズ, yuniiku ユニ ニ ク ), kemudian pada pertengahan zaman Meiji masuk kata yang berasal dari bahasa Jerman (misalnya, arubaito アルバイト, teema テーマ, zeminaaru ゼミナール), bahasa Italia (misalnya, opera オペラ, soro ソロ, madonna マドンナ), bahasa Rusia (misalnya, toroika トロイカ, noruma ノルマ), dan lain-lain

\section{Bentuk Kata Serapan Bahasa Jepang} (Gokei 語形)

Dilihat dari bentuknya, silabel (onsetsu 音節) kata serapan bahasa Jepang (gairaigo 外来語) terdiri dari 3 sampai 7 silabel. Kata paling banyak adalah yang tediri dari 4 silabel seperti kata sukaato ス カート, weisuto ウエスト, namun yang terdiri dari 3 silabel pun relatif banyak seperti peeji ページ, kooto コート. Selain itu kekhasan gairaigo lainnya adalah adanya kata yang panjang, yang terdiri dari
5 sampai 7 silabel seperti taaminaru タ ーミナル, deddobooru デッドボール, komyunikeeshon コミュニケーション, dan lain-lain.

Kata bahasa asing yang diserap dalam bahasa Jepang mengalami penyesuaian dengan bahasa Jepang sebagai berikut.

\section{Proses Pembantukan Adaptasi}

Adaptasi adalah proses penyesuaian bahasa asing dengan kaidah bahasa setempat. Proses adaptasi yang terjadi pada gairaigo adalah sebagai berikut.

1) Mengalami proses adaptasi berupa perubahan pengucapan sesuai pelafalan bahasa Jepang.

Sebagai akibat adaptasi vokal bahasa asli menjadi silabel, maka bentuk gairaigo menjadi lebih panjang dari kata aslinya, misalnya kata strike menjadi sutoraiku ストライク dalam bahasa Jepang.

2) Mengalami proses penyingkatan.

Banyaknya gairaigo yang memiliki kata yang panjang memunculkan fenomena penyingkatan kata serapan bahasa Jepang, misalnya infureeshon インフレー ション menjadi infure インフレ, arubaito アルバイト menjadi baito バイト, eaakondishon エアーコンディション menjadi eakon エアコン.

3) Mengalami adaptasi gramatikal berupa penyingkatan pelafalan penanda jamak ' $-s$ ', artikel 'the', dan lainnya pada kata asli bahasa Inggris, misalnya pada katakata sebagai berikut.

- $\quad$ sunglasses menjadi sangurasu サングラス

- $\quad$ smoked salmon menjadi sumooku saamon スモークサーモン

- on the air menjadi onea オン・エア

4) Mengalami adaptasi berupa perubahan bunyi menjadi lebih simpel.

Karena jumlah konsonan dan vokal dalam bahasa Jepang sedikit, maka pelafalan kata bahasa asli diwakilkan dengan bunyi yang paling mendekati dan 
mirip dengan bahasa Jepang, sehingga dibandingkan bahasa aslinya pelafalan gairaigo menjadi lebih sederhana, misalnya pada kata bahasa Inggris right 'benar' dan light 'cahaya' menjadi raito ライト, bus 'bis' dan bath 'mandi'menjadi basu バス. Selain itu kata bahasa asing yang tidak mempunyai padanan bunyi dalam bahasa Jepang akan menggunakan bunyi apa adanya bahasa aslinya, seperti [v] menjadi「ヴ」, [tsi] menjadi「ツイ」. Misalnya seperti pada kata Venesia (kota di Italia) dapat ditulis menjadi 「ヴェネ チア」,「ヴェネツイア」,「ベネチア」, 「ベネツイア」.

5) Mengalami perubahan aksen menjadi tinggi rendah (koutei 高低) seperti bahasa Jepang, pada aksen bahasa Inggris yang kuat lemah (kyoujaku 強 弱).

Dilihat dari kelas katanya, sebagian besar gairaigo merupakan nomina, selanjutnya terdapat sedikit adjektiva yang kebanyakan merupakan adjetiva na, misalnya modan na モダンな, furesshu na フレッシュな. Selain itu terdapat gairaigo berupa prefiks seperti anchiteikokushugi $\underline{\boldsymbol{P}}$ ンチ帝国主義, posutomodanizumu ポス卜 モダニズム, maruchiningen マルチ人間; dan sufiks seperti otomechikku乙女チック, koodoresu コードレス.

\section{Proses Adopsi}

Proses adopsi adalah kata serapan yang masuk ke dalam kosa kata bahasa setempat melalui perubahan konsep dan arti. 1) Adopsi konsep dan arti.

Pada kata serapan bahasa Jepang terdapat adopsi konsep dan arti secara utuh, seperti pada kata kaaten カーテン.

Tetapi ada pula adopsi demikian yang kata serapannya kemudian dibuat kata terjemahannya (honyakugo 翻訳語) dalam bahasa Jepang, misalnya pada kata「konpyuuta コンピュータ dan denshi keisanki 電子計算機」, 「niizu二
ーズ dan hitsuyousei 必要性」,「meritto 阵 dan riten 利点」, 「risuku リスク dan kikensei 危険性」, 「biggu ビッグ dan ookii 大きい」,「doraibaa ドライバ 一 dan untenshi 運転士」.

Makna pasangan gairaigo dan honyakugo tersebut ada yang persis sama, misalnya pada kata konpyuuta コンピュ 一夕 dan denshi keisanki 電子計算機. Ada pula yang meskipun bermakna sama, namun berbeda penggunaannya dalam kalimat, seperti pada pasangan kata doraibaa

ドライバー dan

untenshi 運転士. Kedua kata tersebut sama-sama bermakna 'pengemudi', tetapi dalam bahasa Jepang ada frasa takushi no doraibaa タクシーのドライバ — namun tidak ada frasa shinkansen no doraibaa 新幹線のドライバー.

2) Adopsi sebuah kata menjadi kata dengan pergeseran konsep dan makna.

Adopsi seperti ini misalnya terdapat pada kata feminisuto フェミニスト. Pada bahasa aslinya feminist berarti wanita yang mendukung persamaan hak antara pria dan wanita, sedangkan pada kata serapan bahasa Jepang (gairaigo), feminisuto フェミニスト berarti pria yang memperlakukan wanita secara khusus.

3) Adopsi sebuah kata dari sumber yang sama menjadi beberapa kata dengan konsep dan makna yang berbeda.

Adopsi seperti ini disebut dengan nijougo 二畳語 atau doublet. Pada adopsi semacam ini kata yang berasal dari bahasa yang sama diserap sebagai gairaigo menjadi kata dengan bentuk dan makna yang berbeda, misalnya kata bahasa Inggris strike masuk sebagai gairaigo menjadi sutoraiku ストライク yang merupakan istilah dalam olah raga basebal, dan sutoraiki ストライキ yang berarti persatuan buruh. Kedua kata tersebut masuk ke Jepang sebagai dua kata yang berbeda. Kemudian contoh lainnya adalah kata dari sumber yang sama bermakna kartu menjadi karuta 力 
Tersedia online di http://ejournal.undip.ac.id/index.php/kiryoku

ルタ dari bahasa Portugis menjadi alat permainan, karute カルテ dari bahasa Jerman menjadi kartu catatan periksa dokter, kaado カード dari bahasa Inggris menjadi bermakna kertas kecil, yang biasa digunakan untuk menyebut kartu kredit dan cash card.

Penggunaan gairaigo umumnya menimbulkan kesan kebarat-baratan dan modern, misalnya bila membandingkan ketiga kata berikut ini, yadoya 宿屋, ryokan 旅館, dan hoteru ホテル, maka kata hoteru ホテル lah yang paling berkesan modern.

Masuknya gairaigo memperkaya kosa kata dan khasanah kebahasaan bahasa setempat, sehingga pengguna dapat berekspresi dengan lebih presisi; misalnya kata bahasa Jepang dengan relasi makna sinonim bermakna 'batal' berikut ini, yaitu kata torikeshi 取り消し, kaiyaku 解約, dan kyanseru キャンセル. Ketiga kata tersebut digunakan pada kesempatan dan situasi yang berbeda; torikeshi 取り消 digunakan untuk menyatakan makna membatalkan janji dan lain-lain; kaiyaku 解約 digunakan untuk menyatakan makna membatalkan kontrak asuransi; dan kyanseru キャンセル digunakan untuk menyatakan makna membatalkan reservasi hotel dan tiket pesawat.

Dari kedua contoh di atas dapat dipahami bahwa kata yadoya 宿屋 dan torikeshi 取り消し memiliki makna lebih luas dan dapat digunakan secara umum, sedangkan hoteru ホテル dan kyanseru キ ヤンセル terbatas.

Selain itu, gairaigo memiliki fungsi eufemisme yaitu sebagai penghalus ungkapan yang dirasa kasar sehingga berkesan tidak vulgar, misalnya pada kata bersinonim berikut ini, toire トイレ vs benjo 便所, roon ローン vs shakkin 借金, oodaa suru オーダーする vs atsuraeru 誂える vs chuumon suru 注文する. Kata toireトイレ, roon ローン, dan oodaa suru
オーダーする berkesan lebih sopan digunakan dibanding kata bermakna sama dalam bahasa Jepang asli.

\section{SIMPULAN}

Sebagai hasil penelitian diperoleh simpulan sebagai berikut.

1. Gairaigo merupakan kata serapan bahasa Jepang yang berasal dari negara barat khususnya dan bahasa lainnya, seperti Portugis, Spanyol, Inggris, Belanda, Perancis, Jerman, Italia, Rusia, dan lain-lain

2. Bentuk gairaigo yang paling banyak terdiri dari 4 silabel, namun adapula yang terdiri dari, 3, 5, 6, dan 7 silabel.

3. Proses pembentukan gairaigo menjadi bahasa Jepang melalui proses adaptasi dan adopsi. Proses adaptasi gairaigo berupa adaptasi pelafalan, penyingkatan kata, adaptasi gramatikal, perubahan bunyi, dan perubahan aksen. Dan adopsi berupa adopsi konsep dan arti; adopsi kata menjadi kata dengan pergeseran konsep dan makna; dan adopsi sebuah kata dari sumber yang sama menjadi beberapa kata dengan konsep dan makna yang berbeda.

\section{DAFTAR PUSTAKA}

Akimoto, Miharu. 2002. Yoku Wakaru Goi. Tokyo : Aruku.

Chaer, Abdul. 2009. Pengantar Semantik Bahasa Indonesia. Jakarta: Rineka Cipta.

dkk. 2010. Sosiolinguistik : Perkenalan Awal. Jakarta: Rineka Cipta.

Djajasudarma, Fatimah. 2010. Metode Linguistik : Ancangan Metode Penelitian dan Kajian. Bandung : Refika Aditama.

Imran, Indiyah. 2005. Kata Serapan dalam Bahasa Indonesia. dalam Prosiding 
Seminar Nasional PESAT. Jakarta : Universitas Gunadarma, hlm. 17-21.

Soelistyowati, Diah. 2010. Pembentukan

Kata Pinjaman (Gairaigo) Dalam
Bahasa Jepang. dalam Jurnal Lite Volume 6 Nomor 2. Semarang: Universitas Dian Nuswantoro, hlm.152-171. 